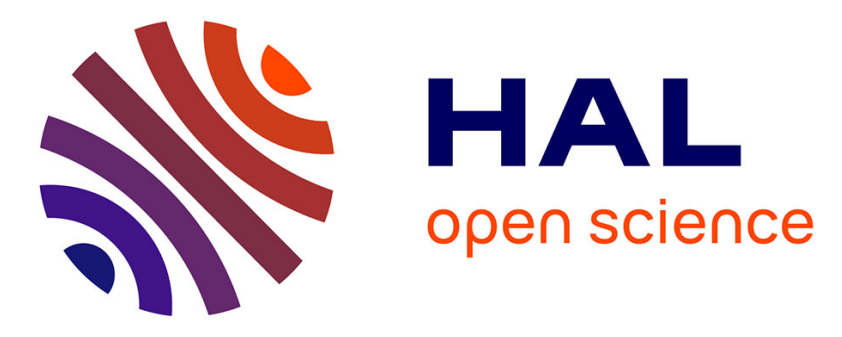

\title{
Eddy Covariance Measurements over Grasslands
}

\author{
Georg Wohlfahrt, Katja Klumpp, Jean-François J.-F. Soussana
}

\section{To cite this version:}

Georg Wohlfahrt, Katja Klumpp, Jean-François J.-F. Soussana. Eddy Covariance Measurements over Grasslands. Eddy Covariance A Practical Guide to Measurement and Data Analysis, Springer Atmospheric Sciences, 11 p., 2012, Springer Atmospheric Sciences, 978-94-007-2350-4 978-94-007-23511. 10.1007/978-94-007-2351-1 . hal-02804884

\section{HAL Id: hal-02804884 https://hal.inrae.fr/hal-02804884}

Submitted on 5 Jun 2020

HAL is a multi-disciplinary open access archive for the deposit and dissemination of scientific research documents, whether they are published or not. The documents may come from teaching and research institutions in France or abroad, or from public or private research centers.
L'archive ouverte pluridisciplinaire HAL, est destinée au dépôt et à la diffusion de documents scientifiques de niveau recherche, publiés ou non, émanant des établissements d'enseignement et de recherche français ou étrangers, des laboratoires publics ou privés. 


\title{
Chapter 13 \\ Eddy Covariance Measurements over Grasslands
}

\author{
Georg Wohlfahrt, Katja Klumpp, and Jean-François Soussana
}

In this chapter we first provide a historic overview of - and outline some of the peculiarities associated with - grassland eddy covariance flux measurements, elaborate on the additional terms that need to be quantified when estimating the grassland net ecosystem carbon balance and finally discuss some of the challenges associated with upcoming nitrous oxide and methane flux measurements in managed grasslands.

\subsection{Historic Overview of Grassland Eddy Covariance Flux Measurements}

One of the first latent/sensible heat flux measurements by means of the eddy covariance method were done in 1950 by Swinbank (1951) over a grassland. At that time and during the following years, experimental evaluations of the eddy covariance method were focused on understanding the turbulent properties of surface layer and on mastering the technical challenges posed by the available equipment. Technical advances in sonic anemometers and scalar sensors then led to more routine applications of the eddy covariance method by the mid-1980s when the scientific interest was already to determine the source/sink strength of grassland ecosystems for latent/sensible heat and trace gases such as nitrogen oxides, ozone and carbon dioxide $\left(\mathrm{CO}_{2}\right)$ (Delany et al. 1986; Kim and Verma 1990; Verma et al. 1989; Zeller et al. 1989). These studies, however, were usually

\footnotetext{
G. Wohlfahrt $(\triangle)$

Institute of Ecology, University of Innsbruck, Innsbruck, Austria

e-mail: Georg.Wohlfahrt@uibk.ac.at

K. Klumpp • J.-F. Soussana

INRA, Grassland Ecosystem Research (UREP), Clermont-Ferrand, France

e-mail: katja.klumpp@clermont.inra.fr; Jean-Francois.Soussana@clermont.inra.fr
} 
confined to a few months and it was not until 1996 when the first year-round carbon dioxide and energy eddy covariance flux measurements over grasslands were initiated (Meyers 2001; Suyker and Verma 2001). During those early years of the FLUXNET project, the majority of sites were situated in forest ecosystems (only 3 out of 34 sites listed in Baldocchi et al. (2001) were non-forest ecosystems). This changed dramatically at the beginning of the twenty-first century when two EU projects dedicated to grassland ecosystems were initiated: CarboMont (Cernusca et al. 2008) and GreenGrass (Soussana et al. 2007). At about the same time, eddy covariance flux measurements were also started at several sites in the large grassland areas of northern America (e.g. Flanagan et al. 2002; Hunt et al. 2004) and central Asia (e.g. Kato et al. 2004; Li et al. 2005). By now, the relative number of grassland flux towers within FLUXNET is approximately equal to the global percentage land cover of grasslands (http://www.fluxdata.ornl.gov).

\subsection{Peculiarities of Eddy Covariance Flux Measurements over Grasslands}

In the following we aim at complementing the previous chapters by identifying and giving examples for issues specific to eddy covariance flux measurements over grassland ecosystems.

A major difference between eddy covariance flux measurements over grasslands as compared to forests, or more generally between tall and short canopies like cropland and wetland, is that flux measurements over grasslands are made closer to the ground surface. This entails the advantage of the storage flux usually being small as compared to the eddy flux (see Eq. 1.24 in Sect. 1.4.2) and that any error in the quantification of the storage flux will have comparably small numerical consequences for the derived net ecosystem $\mathrm{CO}_{2}$ exchange (NEE). For example, for a measurement height of $3 \mathrm{~m}$ and a typical averaging period of $30 \mathrm{~min}$, a uniform $1 \mathrm{ppm}$ change in $\mathrm{CO}_{2}$ mole fraction translates to a storage flux of only $0.07 \mu \mathrm{mol} \mathrm{CO}_{2} \mathrm{~m}^{-2} \mathrm{~s}^{-1}$ (at $20^{\circ} \mathrm{C}$ and a static air pressure of $101.3 \mathrm{kPa}$ ). At the grassland study site Neustift (Austria; Wohlfahrt et al. 2008a) the long-term storage flux (sign removed) amounts to $0.03 \pm 0.04 \mu \mathrm{mol} \mathrm{CO} \mathrm{CO}^{-2} \mathrm{~s}^{-1}$, which is more than two orders of magnitude smaller than the corresponding average night-time $\left(6 \mu \mathrm{mol} \mathrm{CO} \mathrm{m}^{-2} \mathrm{~s}^{-1}\right)$ and midday $\left(-10 \mu \mathrm{mol} \mathrm{CO} \mathrm{Cm}^{-2} \mathrm{~s}^{-1}\right) \mathrm{NEE}$. The lower measurement height at grassland sites, however, causes co-spectra to shift to higher frequencies, as compared to forest sites (see also Sects. 1.5.4 and 4.1.3). This in turn has implications for flux loss due to low- and high-pass filtering (Sect. 4.1.3.2) associated to a certain degree with any eddy covariance system and the corrections required for eliminating this bias (Massman 2000). As a consequence, frequency response corrections tend to be higher for grassland as compared to forest sites (Fig. 13.1), in particular at high wind speeds and/or with stable stratification when co-spectra are characterised by larger high-frequency contents (Kaimal and Finnigan 1994). Differences between typical grassland and 


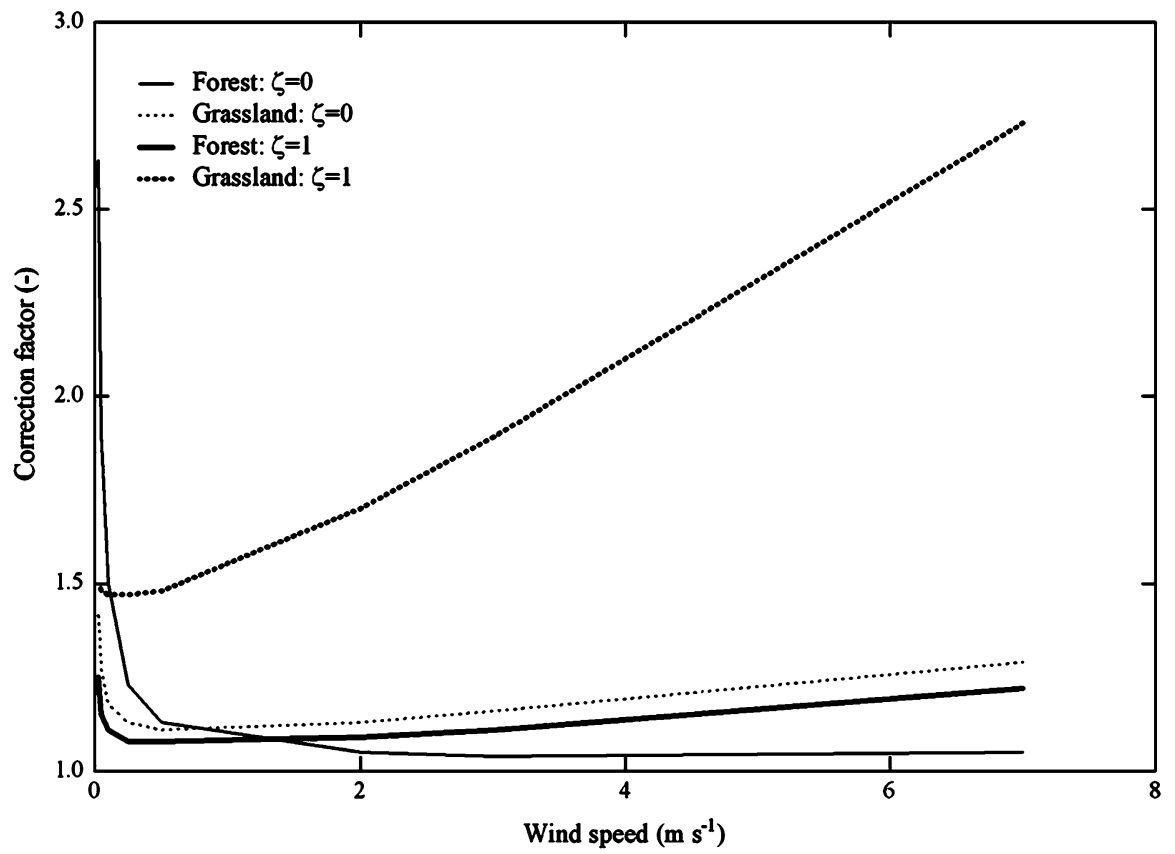

Fig. 13.1 Frequency response correction factors as a function of horizontal wind speed for hypothetical forest (measurement height $=30 \mathrm{~m}$, zero-plane displacement height $=14 \mathrm{~m}$ ) and grassland (measurement height $=3 \mathrm{~m}$, zero-plane displacement height $=0.7 \mathrm{~m}$ ) site for nearneutral $(\zeta=0)$ and stable $(\zeta=1)$ conditions. Calculations have been performed for a $30 \mathrm{~min}$ averaging period (no de-trending) and for the combination of a sonic anemometer (negligible time response, path-length $=0.15 \mathrm{~m}$ ) and an open-path instrument (response time $=0.1 \mathrm{~s}$, pathlength $=0.15 \mathrm{~m}$ ) separated laterally by $0.2 \mathrm{~m}$ and assumed a co-spectral reference model according to Kaimal and Finnigan (1994)

forest frequency response correction factors diminish or even reverse at very low wind speeds, when high-pass filtering associated with block averaging and any detrending operations leads to a relatively larger flux loss for forests due to the larger low-frequency content (Fig. 13.1).

A major challenge for conducting eddy covariance flux measurements in managed grasslands is the fact that the footprint is often heterogeneous due to different land uses present (e.g. a mix of grass- and croplands), different management intensities (e.g. number of grazing animals, cutting frequency, fertiliser type and quantity), temporal asynchrony in management activities (e.g. cutting events occurring at different dates), as well as landscapes with complex topography. Under these circumstances, a careful site selection, which takes the surface heterogeneity into account, is required. As an alternative to the EC method, chamber-based measurements may be suitable for monitoring NEE from short-plant ecosystems in complex topography (Risch and Dougas 2005; Li et al. 2005; Schmitt et al. 2010). 
Footprint models (see Chap. 8) may be used to determine, for any given measurement height and atmospheric conditions, the likely extent of the source area (Schmid 2002). An illustrative example is given in Fig. 13.2, which shows the NEE at the study site Neustift (Austria) for a situation where the first $100 \mathrm{~m}$ of the daytime source area had regrown after a cut 11 days earlier and were followed further upwind by grass which had been cut 3 weeks before and thus did have more time to regrow. The NEE in these two areas was measured concurrently by means of transparent chambers (Wohlfahrt et al. 2005). The source area weighted chamber flux (Fig. 13.2) corresponds nicely with the NEE measured by eddy covariance (slope and $y$-intercept of a linear regression not significantly different from unity and zero, respectively) confirming the validity of the footprint model by Hsieh et al. (2000). During the morning hours, the young grass, which as compared to the older grass exhibits a relatively modest net $\mathrm{CO}_{2}$ uptake, contributes most to the flux measured by the eddy covariance tower (up to $95 \%$ of flux originates from young grass). During the course of the day this contribution diminishes continuously (down to 41\%), however; because the NEE of the older grass diminishes as well, measured and modelled $\mathrm{CO}_{2}$ fluxes change relatively little. This example is meant to show the potential footprint analysis offers in analysing eddy covariance grassland data in situations where management leads to heterogeneities in the footprint. However, except for very simple situations (e.g. Marcolla and Cescatti 2005) and/or if additional measurements are available as in the example shown in Fig. 13.2, it will usually be difficult to partition fluxes based on footprint models. Rather footprint models can be used for guiding site selection and tower setup for maximising data capture from the grassland of interest and as a post-processing quality control criterion (Novick et al. 2004) for excluding flux measurements contaminated by heterogeneities in the footprint.

The low measurement height of grassland flux towers and associated relatively small footprint offer the advantage of making grasslands study sites amenable to manipulation at the field scale. Adopting treatment and control footprints, factorial experiments can be designed which combine the strengths of the EC method, that is, near-continuous spatially integrated flux monitoring, with the explanatory power of causal analysis offered by classical ecological factorial experiments. With identical equipment, land-use history and near-identical environmental conditions, systematic uncertainties are minimised (Ammann et al. 2007), allowing accurate determination of treatment effects. To date such experiments have been limited to changes in management (Allard et al. 2007; Ammann et al. 2007); however, manipulations of environmental factors (e.g. additional precipitation) seem possible as well, and we in fact expect major new developments in this direction in the near future.

Another issue with, in particular managed, grasslands is their rapid growth or regrowth after grazing/cutting, which is reflected in rapid changes of the NEE and energy fluxes (Hammerle et al. 2008; Wohlfahrt et al. 2008a). Imputation of inevitable gaps in EC time series (Falge et al. 2001), a standardised step in the processing of FLUXNET data (see also Chap. 6), needs to take these rapid changes into account (Ammann et al. 2007). Thereby a compromise between the length of the time window, which should be a short as possible in order to capture the dynamic 


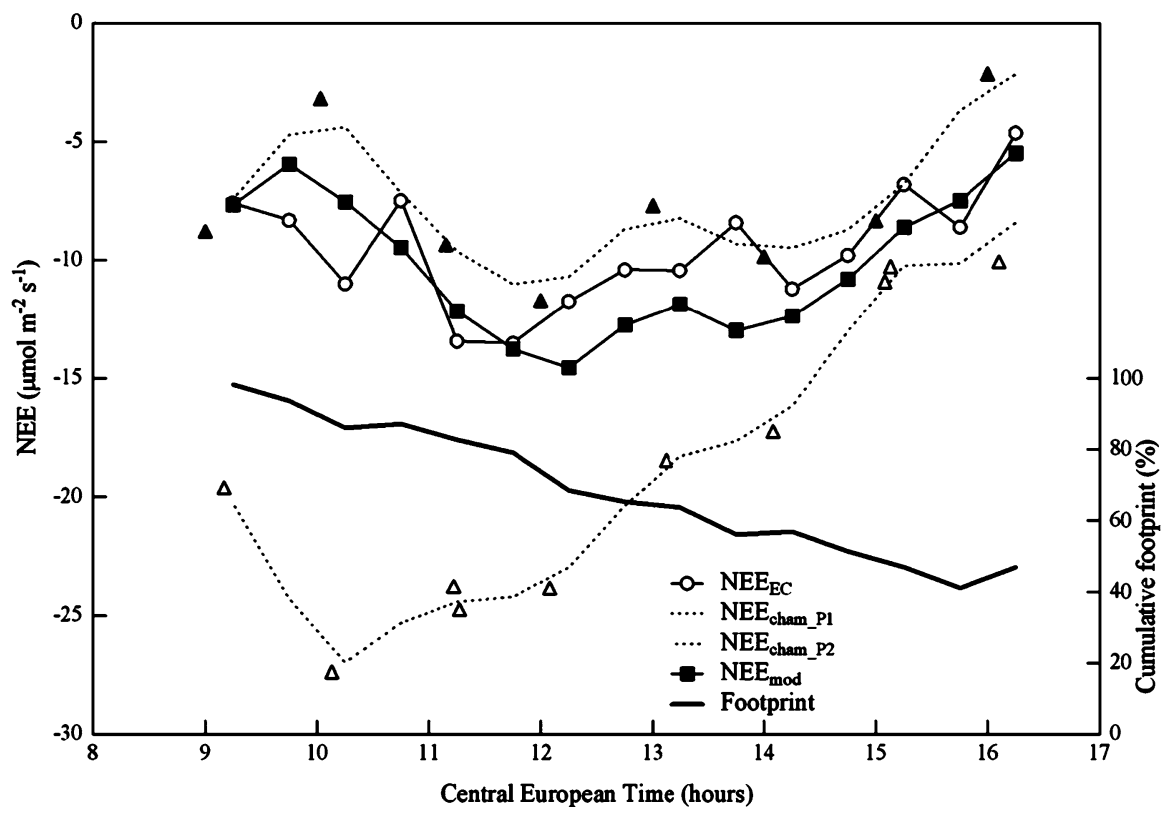

Fig. 13.2 Example illustrating the effect of a bimodal $\mathrm{CO}_{2}$ sink strength distribution in the footprint of an eddy covariance tower on the measured net ecosystem $\mathrm{CO}_{2}$ exchange (NEE $\mathrm{EC}$ ). The area immediately upwind of the tower (Plot 1) had been cut 11 days before measurements and was followed further upwind by an area (Plot 2) which had been cut 3 weeks before. NEE on these two plots $\left(\mathrm{NEE}_{\text {cham_P1 }}, \mathrm{NEE}_{\text {cham_P2 }}\right)$ was measured by means of transparent chambers as described in Wohlfahrt et al. (2005). Based on the footprint model by Hsieh et al. (2000) the expected NEE at the EC tower $\left(\mathrm{NEE}_{\text {mod }}\right)$ was then calculated as the source-area weighted average of the NEEs measured by chambers. Unpublished data by Wohlfahrt G. and Drösler M. from the study site Neustift (Austria)

behaviour, and the number of data upon which gap-filling is based, which should be as large as possible for statistical significance, has to be achieved (see Sect. 6.3.2.1 for further details).

\subsection{Estimating Grassland Carbon Sequestration from Flux Measurements}

An alternative to the direct measurement of carbon (C) stock changes in grasslands (Conant et al. 2001) is to measure the net balance of $\mathrm{C}$ fluxes (i.e. net ecosystem carbon balance, NECB; Chapin et al. 2006) exchanged at the system boundaries. Using this approach changes in $\mathrm{C}$ stocks can be detected within 1 year. In contrast, direct measurements of stock changes by soil coring require several years or even several decades to detect significant effects given the high variability amongst 
samples (Arrouays et al. 2003). The main drawback of flux measurements, however, is that several C fluxes may need to be quantified (Soussana et al. 2010): (1) gaseous $\mathrm{C}$ exchange with the atmosphere, (2) particulate organic $\mathrm{C}$ fluxes, (3) dissolved $\mathrm{C}$ flux in waters and lateral transport of soil $\mathrm{C}$ through erosion (see also Sect. 13.4). The NECB $\left(\mathrm{gC} \mathrm{m}^{-2}\right.$ year $\left.^{-1}\right)$ is the mass balance of all these fluxes (Eq. 13.1). It should be noted that NBP (Net Biome Productivity) is another term frequently used when scaling up NECB from plot to regional scale (e.g. Schulze et al. 2009).

$$
\begin{aligned}
\mathrm{NBP}= & \mathrm{NECB}=\mathrm{NEP}+\mathrm{F}_{\mathrm{CH} 4-\mathrm{C}}+\mathrm{F}_{\mathrm{VOC}}+\mathrm{F}_{\text {fire }}+\mathrm{F}_{\text {manure }} \\
& +\mathrm{F}_{\text {harvest }}+\mathrm{F}_{\text {animal-products }}+\mathrm{F}_{\text {leach }}+\mathrm{F}_{\text {erosion }}
\end{aligned}
$$

Adopting a sign convention where a positive $\mathrm{C}$ flux indicates a gain by the ecosystem and a negative flux a loss to the atmosphere, the following groups of fluxes (units of $\mathrm{gC} \mathrm{m}^{-2}$ year $^{-1}$ ) can be distinguished: fluxes which constitute a clear gain by the ecosystem, such as $\mathrm{C}$ imports through manure $\left(\mathrm{F}_{\text {manure }}\right)$, and negative fluxes such as carbon exports through harvesting $\left(\mathrm{F}_{\text {harvest }}\right)$, animal products ( $\left.\mathrm{F}_{\text {animal-products }}\right)$, erosion $\left(\mathrm{F}_{\text {erosion }}\right)$, leaching $\left(\mathrm{F}_{\text {leach }}\right.$; organic and/or inorganic carbon) and fire emissions $\left(\mathrm{F}_{\text {fire }}\right)$. Both positive and negative fluxes have been reported for the net ecosystem $\mathrm{CO}_{2}$ uptake (NEP, see Sect. 9.2), $\mathrm{CH}_{4}\left(F_{\mathrm{CH} 4-\mathrm{C}}\right)$ and volatile organic compound $\left(F_{\text {VOC }}\right)$ exchange (Soussana et al. 2007; Wohlfahrt et al. 2008a; Ruuskanen et al. 2011).

Depending on the system studied and its management, some of these fluxes can be neglected for NECB calculation. For instance, fire emissions by grasslands are very low in temperate regions like Europe (i.e., below $1 \mathrm{gC} \mathrm{m}^{-2}$ year $^{-1}$ over $1997-$ 2004), whilst they reach 10 and $100 \mathrm{gC} \mathrm{m}^{-2}$ year $^{-1}$ in Mediterranean and in tropical grasslands, respectively (Van der Werf et al. 2006). Erosion $\left(F_{\text {erosion }}\right)$ is also rather insignificant in permanent grasslands (e.g. in Europe), but can be increased by tillage in the case of sown grasslands. The global map of $F_{\text {erosion }}$ created by Van Oost et al. (2007) indicates that grassland $\mathrm{C}$ erosion rates are usually below $5 \mathrm{gC} \mathrm{m}^{-2}$ year $^{-1}$, even in dry tropical grasslands (Van Oost et al. 2007). VOC emissions by grassland systems are increased in the short term by cutting (Ruuskanen et al. 2011) and tend to be higher with legumes than with grass species (Davison et al. 2008). However, VOC fluxes from grasslands, even if some VOC compounds include several C atoms, are usually at least 1 order of magnitude smaller and can usually be neglected in terms of carbon exchange. Therefore, for temperate managed grasslands, Eq. 13.1 can be simplified as (Allard et al. 2007)

$$
\mathrm{NECB}=\mathrm{NEP}+F_{\mathrm{CH} 4-\mathrm{C}}+F_{\text {manure }}+F_{\text {harvest }}+F_{\text {animal-products }}+F_{\text {leach }}
$$

Since eddy flux covariance measurements use a free air technique, as opposed to enclosures, there is no disturbance of the measured area, which can be freely accessed by herbivores. $\mathrm{CO}_{2}$ belched by ruminants during grazing (digestive + metabolic $\mathrm{CO}_{2}$ ), which can be measured by the $\mathrm{SF}_{6}$ method (PinaresPatiño et al. 2007), is thus included in NEP measurements. It has no direct effect on 
the atmospheric $\mathrm{CO}_{2}$ concentration, because it is 'short-cycling' carbon, which has been fixed by plants earlier.

Quite often not all components of the NECB budget are measured. For example, DOC/DIC losses as well as $\mathrm{C}$ exports in milk and meat products are sometimes neglected. Siemens and Janssens (2003) have estimated at the European scale the average DOC/DIC loss at $11 \pm 8 \mathrm{gC} \mathrm{m}^{-2} \mathrm{year}^{-1}$. This flux tends to be highly variable depending on soil $(\mathrm{pH}$, carbonate) and climate (rainfall, temperature) factors and it could reach higher values in wet tropical grasslands, especially on calcareous substrate. Assuming a value at the upper range of this estimate, would reduce the grassland NBP by $20 \%$. In contrast, the role of organic C exports is relatively small with meat production systems (e.g. 1.6\% of NBP, Allard et al. 2007) but can be higher with intensive dairy production systems.

\subsection{Additional Measurements}

Calculation of the NECB (Eq. 13.2) requires several additional carbon fluxes in addition to the $\mathrm{CO}_{2}$ and $\mathrm{CH}_{4}$ fluxes, treated in Sects. 13.2 and 13.5, respectively, to be quantified. In a cutting regime, a large part of the primary production is exported from the plot (as hay or silage), and may be compensated by organic $\mathrm{C}$ imports through cattle slurry and liquid manure. To determine a complete $\mathrm{C}$ budget requires quantification of the amount of harvested dry-matter and organic fertiliser as well as the corresponding $\mathrm{C}$ content $\left(\mathrm{gC} \mathrm{m}^{-2}\right.$ year $\left.^{-1}\right)$. Under grazing, up to $60 \%$ of the above-ground dry-matter production is ingested by domestic herbivores (Lemaire and Chapman 1996), whereas a large part of the ingested $\mathrm{C}$ is emitted as $\mathrm{CO}_{2}$ and $\mathrm{CH}_{4}$ shortly after intake. The magnitude of these fluxes largely depends on quality of ingested biomass and number, weight and type of animals (i.e., sheep, heifers, dairy cows, etc.). For example, with the $\mathrm{SF}_{6}$ dual tracer technique (e.g. PinaresPatiño et al. 2007), methane emission comprised between 0.33 and $0.45 \mathrm{~g} \mathrm{CH}_{4}$ $\mathrm{kg}^{-1} \mathrm{LW} \mathrm{day}^{-1}$ for heifers and bulls and reached $0.68-0.97 \mathrm{~g} \mathrm{CH}_{4} \mathrm{~kg}^{-1} \mathrm{LW} \mathrm{day}^{-1}$ for lactating cows (Soussana et al. 2007). Quantity and quality of herbage biomass offered to animals can be determined by grazing exclusion cages. To closely follow the vegetation dynamics, cages should be moved and cut at least on a monthly basis. Detailed analyses of the harvested biomass offers further insights into the fraction of senescent plant material and plant functional groups (i.e., grass, forbs and legumes). The potential herbage production of the pasture, which is closely related to gross primary productivity, can be estimated, by measuring the monthly biomass regrowth $\left(\mathrm{g} \mathrm{DM} \mathrm{m}^{-2}\right.$ day $\left.^{-1}\right)$.

The non-digestible C (25-40\%) of the intake is usually returned to pastures/hay meadows in excreta (mainly as faeces) and urine for fertilisation. Manure, urine and mineral fertiliser in turn are known to stimulate $\mathrm{N}_{2} \mathrm{O}$ emissions, their magnitude depending on soil humidity conditions at the time of application. Detailed knowledge of stocking rate (mean number of livestock units per unit area), weight and growth of livestock, grazing period, as well as date of fertilisation and meteorological 
soil conditions (i.e., soil water content, soil temperature) are thus helpful for understanding and interpreting eddy covariance data (see also Sect. 13.5).

Because particular managed grasslands exhibit a very dynamic canopy growth, knowledge of the amount of above-ground biomass is crucial for interpreting flux measurements (Hammerle et al. 2008; Wohlfahrt et al. 2008b). The amount of above-ground biomass or the leaf area index (LAI) should thus be determined at least episodically, for example, using destructive harvesting and leaf area determination. Indirect measurements of LAI, by inverting models of within-canopy radiative transfer (Wohlfahrt et al. 2001), or measurements of proxies for aboveground biomass and LAI, for example, canopy height, can be done in an automated fashion using line PAR (Wohlfahrt et al. 2010) and snow height (Jonas et al. 2008) sensors, respectively, and can be combined with direct measurements to yield quantitative high-resolution time series information about vegetation development (Wohlfahrt et al. 2008a).

\subsection{Other Greenhouse Gases}

During the past two decades, a large body of literature has been accumulated on grassland carbon cycling based on eddy covariance flux measurements (e.g. Gilmanov et al. 2007, 2010; Soussana et al. 2007, 2010; Wohlfahrt et al. 2008b). In the near future, we anticipate that these $\mathrm{CO}_{2}$ flux measurements will be increasingly accompanied by flux measurements of the other two important greenhouse gases originating from grasslands, that is, methane $\left(\mathrm{CH}_{4}\right)$ and nitrous oxide $\left(\mathrm{N}_{2} \mathrm{O}\right)$, whose emissions may easily offset any carbon gains due to the larger warming potential (Soussana et al. 2007, 2010). However, due to a combination of source complexity (i.e., spatial and temporal variation), limitations in equipment and methodology, measurements of $\mathrm{CH}_{4}$ and $\mathrm{N}_{2} \mathrm{O}$ fluxes are accompanied by significant uncertainties. $\mathrm{N}_{2} \mathrm{O}$ emissions in soils usually occur in 'hot spots' associated with urine spots and particles of residues and fertiliser (Flechard et al. 2007). Nitrous oxide emissions from grasslands tend to occur in short-lived bursts following the application of fertilisers (Leahy et al. 2004). Temporal and spatial variations contribute large sources of uncertainty in $\mathrm{N}_{2} \mathrm{O}$ fluxes at the field and annual scales (Flechard et al. 2005). Methane emissions by cattle show temporal and spatial variations, depending upon stocking rate and the quantity and quality of feed consumed (Pinares-Patiño et al. 2007) (see also Sect. 13.4). Additionally, a large variability results from animal behaviour, as animals do not behave at random. Grazing and ruminating is separated in time and space. The area of interest (i.e., paddock) is in most cases larger than measured footprint, which may make it necessary to track animals (e.g. using webcams or laser systems). Moreover, ruminating will create plumes of $\mathrm{CH}_{4}$ that may appear as spikes in the concentration time series, but are in fact 'natural phenomena' which may be unintentionally removed by automated despiking algorithms (Vickers and Mahrt 1997). 
Instrumentation for $\mathrm{CH}_{4}$ and $\mathrm{N}_{2} \mathrm{O}$ EC measurements, have to satisfy four criteria: (Nelson et al. 2002): (1) continuity, that is, the system should be able to operate unattended on a continuous basis; (2) the analyser response time should be on the order of $0.1 \mathrm{~s}$ to capture also the smallest eddies (Monteith and Unsworth 1990); however, sample interval may be much longer as long as the system time response is short enough (see Sect. 10.2.3); (3) a minimal drift should occur during a period of atmospheric stationarity (i.e., $30 \mathrm{~min}$ ); and (4) a precision of 4 and $0.3 \mathrm{ppb}$ for $\mathrm{CH}_{4}$ and $\mathrm{N}_{2} \mathrm{O}$, given an average ambient concentration of 1,800 and $320 \mathrm{ppb}$. Instruments that meet those requirements for $\mathrm{CH}_{4}$ and $\mathrm{N}_{2} \mathrm{O}$ EC measurements are now becoming available. A limited number of closed-path EC measurements have been published using lead salt tunable diode laser (TDL) spectrometers (e.g. Smith et al. 1994; Wienhold et al. 1994; Laville et al. 1999; Hargreaves et al. 2001; Werle and Kormann 2001), quantum cascade (QC) lasers for $\left(\mathrm{CH}_{4}\right.$ and $\mathrm{N}_{2} \mathrm{O}$; Kroon et al. 2007; Neftel et al. 2007; Eugster et al. 2007), off-axis integrated cavity output spectroscopy $\left(\mathrm{CH}_{4}\right.$; Hendriks et al. 2008; Smeets et al. 2009) and as of this writing even open-path $\mathrm{CH}_{4}$ analysers are becoming commercially available. In those studies, $\mathrm{CH}_{4}$ and $\mathrm{N}_{2} \mathrm{O}$ fluxes are measured over time periods ranging from 1 week to several years, yielding averaged emission rates with their standard deviations. The standard deviation, however, is mainly an indication of the temporal variability and does not represent the uncertainty associated with the mean flux (Kroon et al. 2009). Based on 30 min EC fluxes, the relative uncertainty is mainly attributed to relatively small EC fluxes and one-point sampling. On average this term contributes to more than $90 \%$ to the total uncertainty. The other $10 \%$ comprise the uncertainty in correction algorithms for systematic errors (e.g. inadequate footprint, non-stationarity, advection, storage, low- and high-pass filtering, etc.; see also previous chapters). Nevertheless, because the EC method integrates over a large spatial area and provides near-continuous data, EC flux measurements can contribute to more accurate estimates of the net ecosystem exchange of $\mathrm{N}_{2} \mathrm{O}$ and $\mathrm{CH}_{4}$ than estimates based on chamber measurements only.

Acknowledgements Authors acknowledge financial support by the EU (FP 5, 6 and 7) as well as Austrian and French National Science fund, the Tyrolean Science fund, the Austrian Academy of Sciences, the Österreichische Forschungsgemeinschaft and the help of numerous persons who have helped in keeping the eddy covariance flux measurements going over the years.

\section{References}

Allard V, Soussana JF, Falcimagne R (2007) The role of grazing management for the net biome productivity and greenhouse gas budget $\left(\mathrm{CO}_{2}, \mathrm{~N}_{2} \mathrm{O}\right.$ and $\left.\mathrm{CH}_{4}\right)$ of semi-natural grassland. Agric Ecosyst Environ 121:47-58

Ammann C, Flechard CR, Leifeld J et al (2007) The carbon budget of newly established temperate grassland depends on management intensity. Agric Ecosyst Environ 121:5-20

Arrouays D, Jolivet CI, Boulonne L et al (2003) Le Réseau de Mesures de la Qualité des Sols (RMQS) de France. Étude et Gestion des Sols 10:241-250 
Baldocchi DD, Falge E, Gu L et al (2001) FLUXNET: a new tool to study the temporal and spatial variability of ecosystem-scale carbon dioxide, water vapor and energy flux densities. Bull Am Meteorol Soc 82:2415-2435

Cernusca A, Bahn M, Berninger F et al (2008) Preface to CarboMont special feature: effects of land-use changes on sources, sinks and fluxes of carbon in European mountain grasslands. Ecosystems 11:1335-1337

Chapin FS III, Woodwell GM, Randerson JT et al. (2006) Reconciling carbon cycle concepts, terminology, and methods. Ecosystems 9:1041-1050

Conant RT, Paustian K, Elliott ET (2001) Grassland management and conversion into grassland: effects on soil carbon. Ecol Appl 11:343-355

Davison B, Brunner A, Ammann C, Spirig C (2008) Cut-induced VOC emissions from agricultural grasslands. Plant Biol 10:76-85

Delany AC, Fitzjarrald DR, Lenschow DH et al (1986) Direct measurement of nitrogen oxides and ozone fluxes over grassland. J Atmos Chem 4:429-444

Eugster W, Zeyer K, Zeeman M (2007) Methodical study of nitrous oxide eddy covariance measurements using quantum cascade laser spectrometry over a Swiss forest. Biogeosciences 4:927-939

Falge E, Baldocchi D, Olson R et al (2001) Gap filling strategies for defensible annual sums of net ecosystem exchange. Agric For Meteorol 107:43-69

Flanagan LB, Wever LA, Carlson PJ (2002) Seasonal and interannual variation in carbon dioxide exchange and carbon balance in a northern temperate grassland. Glob Change Biol 8:599-615

Flechard CR, Ambus P, Skiba U et al. (2007) Effects of climate and management intensity on nitrous oxide emissions in grassland systems across Europe. Agr Ecosyst Env 121:135-152

Flechard CR, Neftel A, Jocher $\mathrm{M}$ et al (2005) Bi-directional soil/atmosphere $\mathrm{N}_{2} \mathrm{O}$ exchange over two mown grassland systems with contrasting management practices. Glob Change Biol $11: 2114-2127$

Gilmanov T, Soussana JF, Aires L et al (2007) Partitioning European grassland net ecosystem $\mathrm{CO}_{2}$ exchange into gross primary productivity and ecosystem respiration using light response function analysis. Agric Ecosyst Environ 121:93-120

Gilmanov TG, Aires L, Barcza Z et al (2010) Productivity, respiration, and light-response parameters of world grassland and agroecosystems derived from flux-tower measurements. Rangel Ecol Manage 63:16-39

Hammerle A, Haslwanter A, Tappeiner U et al (2008) Leaf area controls on energy partitioning of a temperate mountain grassland. Biogeosciences 5:421-431

Hargreaves KJ, Fowler D, Pitcairn CER, Aurela, M (2001) Annual methane emission from Finnish mires estimated from eddy covariance campaign measurements. Theor Appl Climatol 70:203213

Hendriks DMD, Dolman AJ, Van der Molen MK et al (2008) A compact and stable eddy covariance set-up for methane measurements using off-axis integrated cavity output spectroscopy. Atmos Chem Phys 8:1-13

Hsieh CI, Katul G, Chi TW (2000) An approximate analytical model for footprint estimation of scalar fluxes in thermally stratified atmospheric flows. Adv Water Resour 23:765-772

Hunt JE, Kelliher FM, McSeveny TM, Ross DJ et al (2004) Long-term carbon exchange in a sparse, seasonally dry tussock grassland. Glob Change Biol 10:1785-1800

Jonas T, Rixen C, Sturm M, Stoeckli V (2008) How alpine plant growth is linked to snow cover and climate variability. J Geophys Res 113:G03013. doi:10.1029/2007JG000680

Kaimal JC, Finnigan JJ (1994) Atmospheric boundary layer flows. Oxford University Press, Oxford, $289 \mathrm{pp}$

Kato T, Tang Y, Gu S, Cui X et al (2004) Carbon dioxide exchange between the atmosphere and an alpine meadow ecosystem on the Qinghai-Tibetan Plateau, China. Agric For Meteorol 124:121-134

Kim J, Verma SB (1990) Components of surface energy balance in a temperate grassland ecosystem. Bound Layer Meteorol 51:401-417 
Kroon PS, Hensen A, Jonker HJJ et al (2007) Suitability of quantum cascade spectroscopy for $\mathrm{CH}_{4}$ and $\mathrm{N}_{2} \mathrm{O}$ eddy co-variance flux measurements. Biogeosciences 4:715-728

Kroon PS, Hensen A, Jonker HJJ et al (2009) Uncertainties in eddy covariance flux measurements assessed from $\mathrm{CH}_{4}$ and $\mathrm{N}_{2} \mathrm{O}$ Observation. Agric For Meteorol. doi:10.1016/j.agrformet.2009.08.008

Laville P, Jambert C, Cellier P (1999) Nitrous oxide fluxes from a fertilized maize crop using micrometeorological and chamber methods. Agric For Meteorol 96:19-38

Leahy P, Kiely G, Scanlon TM (2004) Managed grasslands: a greenhouse gas sink or source? Geophys Res Lett 31:L20507. doi:10.1029/2004GL021161

Lemaire G, Chapman D (1996) Tissue flows in grazed plant communities. In: Hodgson J, Illius AW (eds) The ecology and management of grazing systems. CABI, Wallingford

Li S-G, Asanuma J, Eugster W (2005) Net ecosystem carbon dioxide exchange over grazed steppe in Mongolia. Glob Change Biol 11:1941-1955

Marcolla B, Cescatti A (2005) Experimental analysis of flux footprint for varying stability conditions in an alpine meadow. Agric For Meteorol 135:291-301

Massman WJ (2000) A simple method for estimating frequency response corrections for eddy covariance systems. Agric For Meteorol 104:185-198

Meyers T (2001) A comparison of summertime water and $\mathrm{CO}_{2}$ fluxes over rangeland for wellwatered and drought conditions. Agric For Meteorol 104:185-198

Monteith JL, Unsworth MH (1990) Principles of environmental physics, Edward Arnold, London, 1990

Neftel A, Flechard C, Ammann C (2007) Experimental assessment of $\mathrm{N}_{2} \mathrm{O}$ background fluxes in grassland systems. Tellus B 59:470-482

Nelson DD, Shorter JH, McManus JB (2002) Sub-part-per-billion detection of nitric oxide in air using a thermoelectrically cooled mid-infrared quantum cascade laser spectrometer. Appl Phys B 75:343-350

Novick KA, Stoy PC, Katul GG, Ellsworth DS, Siqueira MBS, Juang J, Oren R (2004) Carbon dioxide and water vapor exchange in a warm temperate grassland. Oecologia 138:259-274

Pinares-Patiño CS, Dhour P, Jouany JP (2007) Effects of stocking rate on methane and carbon dioxide emissions from grazing cattle. Agric Ecosyst Environ 121:30-46

Risch A, Frank DA (2005) Carbon dioxide fluxes in a spatially and temporally heterogeneous temperate grassland. Oecologia 147:291-302

Ruuskanen TM, Müller M, Schnitzhofer R, Karl T, Graus M, Bamberger I, Hörtnagl L, Brilli F, Wohlfahrt G, Hansel A (2011) Eddy covariance VOC emission and deposition fluxes above grassland using PTR-TOF. Atmos Chem Phys 11:611-625

Schmid HP (2002) Footprint modeling for vegetation atmosphere exchange studies: a review and perspective. Agric For Meteorol 113:159-183

Schmitt M, Bahn M, Wohlfahrt G, Tappeiner U, Cernusca A (2010) Land use affects the net ecosystem $\mathrm{CO}_{2}$ exchange and its components in mountain grasslands. Biogeosciences 7:22972309

Schulze ED, Ciais P, Luyssaert S et al (2009) The greenhouse gas balance of Europe: methane and nitrous oxide compensate the carbon sink of EU-25. Nat Geosci 2:842-850

Siemens J, Janssens IA (2003) The European carbon budget: a gap. Science 302:1681

Smeets CJPP, Holzinger R, Vigano R et al (2009) Eddy covariance methane measurements at a Ponderosa pine plantation in California. Atmos Chem Phys 9:8365-8375

Smith KA, Clayton H, Arah JRM et al. (1994) Micrometeorological and chamber methods for measurement of nitrous oxide fluxes between soils and the atmosphere: Overview and conclusions. J Geophys Res 99: 541-16

Soussana JF, Allard V, Pilegaard K et al (2007) Full accounting of the greenhouse gas $\left(\mathrm{CO}_{2}, \mathrm{~N}_{2} \mathrm{O}\right.$, $\mathrm{CH}_{4}$ ) budget of nine European grassland sites. Agric Ecosyst Environ 121:121-134

Soussana JF, Tallec T, Blanfort V (2010) Mitigating the greenhouse gas balance of ruminant production systems through carbon sequestration in grasslands. Animal 4:334-350

Suyker AE, Verma SB (2001) Year-round observations of the net ecosystem exchange of carbon dioxide in a native tallgrass prairie. Glob Change Biol 7:279-289 
Swinbank WC (1951) The measurement of vertical transfer of heat and water vapor by eddies in the lower atmosphere. J Meteorol 8:135-145

Van der Werf GR, Randerson JT, Giglio L et al (2006) Interannual variability in global biomass burning emissions from 1997 to 2004. Atmos Chem Phys 6:3423-3441

Van Oost K, Quine TA, Govers G et al (2007) The impact of agricultural soil erosion on the global carbon cycle. Science 318:626-629

Verma SB, Kim J, Clement RJ (1989) Carbon dioxide, water vapor and sensible heat fluxes over a tallgrass prairie. Bound Layer Meteorol 46:53-67

Vickers D, Mahrt L (1997) Quality control and flux sampling problems for tower and aircraft data. J Atmos Ocean Technol 14:512-526

Werle P, Kormann R (2001) Fast chemical sensor for eddy correlation measurements of methane emissions from rice paddy fields. Appl Opt 40:846-858

Wienhold FG, Klemedtsson L, Galle B (1994) Micrometeorological and chamber methods for measurement of nitrous oxide fluxes between soils and the atmosphere: overview and conclusions. J Geophys Res 99:541-548

Wohlfahrt G, Sapinsky S, Tappeiner U, Cernusca A (2001) Estimation of plant area index of grasslands from measurements of canopy radiation profiles. Agric For Meteorol 109:1-12

Wohlfahrt G, Anfang Ch, Bahn M et al (2005) Quantifying nighttime ecosystem respiration of a meadow using eddy covariance, chambers and modelling. Agric For Meteorol 128:141-162

Wohlfahrt G, Anderson-Dunn M, Bahn M et al (2008a) Biotic, abiotic and management controls on the net ecosystem $\mathrm{CO}_{2}$ exchange of European mountain grasslands. Ecosystems 11:1338-1351

Wohlfahrt G, Hammerle A, Haslwanter A et al (2008b) Seasonal and inter-annual variability of the net ecosystem $\mathrm{CO}_{2}$ exchange of a temperate mountain grassland: effects of weather and management. J Geophys Res 113:D08110. doi:10.1029/2007JD009286

Wohlfahrt G, Pilloni S, Hörtnagl L, Hammerle A (2010) Estimating carbon dioxide fluxes from temperate mountain grasslands using broad-band vegetation indices. Biogeosciences 7: 683-694

Zeller K, Massman W, Stocker D et al (1989) Initial results from the Pawnee eddy correlation system for dry acid deposition research, USDA Forest Service Research Paper RM-282. U.S. Dept. of Agriculture, Forest Service, Rocky Mountain Forest and Range Experiment Station, Fort Collins 